\title{
11. ENHANCING CAREER PRACTITIONERS' UNDERSTANDING AND USE OF ICT IN GUIDANCE AND COUNSELLING
}

\begin{abstract}
This chapter describes the Nordic jointly developed international course on ICT in guidance and counselling. Firstly, the rational for developing such a course is discussed. Secondly the use of research-based framework is elaborated and application of it to the curriculum development is demonstrated.
\end{abstract}

\section{INTRODUCTION}

European and Nordic case studies and reviews strongly indicate that, as elsewhere, demand for guidance far exceeds the supply of services, and that this need cannot be met by relying exclusively on traditional models of guidance (e.g. ELGPN, 2010; NOU, 2016; Sultana, 2004; Sultana \& Watts, 2006; Valtiontalouden tarkastusvirasto, 2015; Watts \& Sultana, 2004; Zelloth, 2009). In a difficult economic climate, lifelong guidance policies contextualise the value of consistent and coherent guidance services in a wider societal spectrum. Europe and international policy documents (e.g. Cedefop, 2011; Eurobarometer, 2014; European Council 2004, 2008; OECD, 2004a, 2004b) reflect a growing consensus that the role of Information and Communication Technology (ICT) in the guidance service sector is both important and increasingly essential. As demand for services continues to grow, we need to continually review and improve our service delivery modes and mechanism in a cost-effective manner. To this end, technology provides opportunities to extend services, especially reaching out to those in remote locations. To maximise these opportunities, it will be of importance to ensure that career practitioners are equipped with the requisite ICT competencies.

Rapid development in information and communication technology (ICT) has changed society fundamentally over the past two decades (e.g. Hoonakker, 2014; ITU, 2017). This technological revolution has given people unprecedented access to diverse information and has enabled inexpensive and instantaneous communication worldwide. In an evolving society, career professionals must continuously reevaluate techniques and delivery systems if they are to provide meaningful and 
effective services to the various populations they serve. As technological advances change how individuals explore and acquire information about education, training and work opportunities, there is a pressing need to more closely align career guidance services and associated professional practices with these new technologies (e.g. Bimrose, Barnes, \& Atwell, 2010; Kettunen, 2017; Kettunen \& Sampson, 2019; Osborn, Dikel, \& Sampson, 2010; Sampson, Kettunen, \& Vuorinen, 2019). The skills and competences in the use of ICT in career guidance and counselling are often considered secondary and are therefore poorly developed in initial and continuing training (Cedefop, 2009; European Commission, 2014). In Nordic and Baltic training programmes, the role of ICT in career guidance is somewhat neglected (e.g. Högskoleverket, 2006; Vuorinen, 2006), and most such programmes do not teach the use of ICT in a professional context (Andreassen \& Einarsdóttir, 2012).

To contribute to the current discussion and to enhance the training of career professionals, this chapter describes an international jointly developed ICT training programme for guidance and counselling practitioners. This draws on experiences and data gathered from Nordic countries, including (a) a mapping grid that explores the current situation in each country; (b) the authors' written documentation when designing the course and c) participants' written reflections about the course. The applied conceptual framework provides a basis for further development of the wider training curriculum.

\section{NORDIC COOPERATION IN COURSE DEVELOPMENT}

The impetus for the course emerged from the VALA Nordplus network. VALA is a network of Nordic and Baltic higher education institutions that train career guidance and counselling professionals in the Nordic and Baltic countries. The network's purpose is to develop the curriculum and educational provisions for career and guidance counselling students, preparing them for work in diverse settings and with clients of all ages. The VALA network started off their work in 2012 by doing curricular comparison among training programmes (Andreassen \& Einarsdóttir, 2012). In the course of this analysis, it became evident that Nordic and Baltic programmes differ widely in their approaches to the role and use of ICT in guidance and counselling. A closer look revealed that most programmes do not address the use of ICT in professional practice (Andreassen \& Einarsdóttir, 2012) and this finding motivated the development of the course described here. The course curriculum was jointly designed and delivered by the Finnish Institute for Educational Research (FI), Malmö University (SWE), eVejledning (DK) and the University of Iceland (IS). The partners have extensive experience of training and research in the use of ICT in guidance and counselling, and they support and work with practitioners in Nordic countries and internationally. Their complementary competences, experience, knowledge and skills encompass higher education (SWE/IS), practical applications (DK), research (FI) and independent work (SWE). 


\section{Course Design}

To enhance course participants' understanding and use of ICT in guidance and counselling contexts, the aim of the course was to make them aware of the variation in the ways that technology interacts with professional practice and to provide opportunities to experiment and practice with ICT and social media in a broader way (Kettunen, 2017). The course is open to degree seeking students and experienced practitioners from various settings, exposing them to learning situations that challenge them to reflect and see the variation in terms of the potential uses of technology in career guidance and counselling. On completing the course, the students should be able to demonstrate increased ICT competency and to apply this in their professional practice. The course is a 5 ECTS course and workload is estimated to be 135 hours of work.

Content development for the course drew on the latest phenomenographic research exploring career practitioners' conceptions of social media and competency for social media in career services (Kettunen, 2017; Kettunen, Sampson, \& Vuorinen, 2015). Phenomenographic studies help to improve practice by exploring variations in participants' experiences of the phenomenon in question, which are revealed by the dimensions of variation which highlight the differences between the conceptions (e.g. Åkerlind, 2008; Kettunen \& Tynjälä, 2017; Runesson, 2006). From an educational point of view, they also reveal what is needed to gain a more complex way of understanding (Marton \& Booth, 1997, p. 111; Runesson, 2006). Kettunen's study (2017) established an empirically derived, evidence-based foundation for the design of such training within a coherent career practice framework. The results revealed a qualitative variation in career practitioners' conceptions of competency, ranging from the ability to use ICT and social media for information delivery to the ability to use ICT and social media for co-careering. The dimensions of variation highlight differences in conceptions, serving to identify critical features to be emphasised in training and curriculum development, and in creating learning objectives for the course. As an outcome of phenomenographic analysis (Marton, 1986, 1994; Marton \& Booth, 1997), the variation theory of learning (Bowden \& Marton, 1998; Marton \& Booth, 1997; Marton \& Tsui, 2004) informed the application of these dimensions to curriculum design (Åkerlind, McKenzie, \& Lupton, 2014).

The course's underlying teaching and learning philosophy is grounded in social constructivist (e.g. Brown, Collins, \& Duguid, 1989) and socio-cultural theories (Säljö, 2001), employing a student-centred approach and problem-based or casebased 21 st century learning principles for professional education. From this view, learning is a situated process, promoting a community of mutually supportive learners. Research-based knowledge is linked to practice through hands-on training and empirical examples provided by instructors and also by participants. The course assigns great importance to student experiments and collaboration in interactive workshops that deepen knowhow in a goal-oriented manner, following the sequence theory-application-discussion. 


\section{J. KETTUNEN ET AL.}

To facilitate the development of reflection and reflective learning, students write a reflective diary during the course. This reflexivity is considered crucial for professional education and training because it integrates theory and practice, transforming experience into new learning and developing new skills by building integrated knowledge bases (e.g. Mezirow, 1990). Mason (2002) characterises reflexivity as intentional learning from experience.

\section{FROM DELIVERING INFORMATION TO CO-CAREERING}

Kettunen's (2017) evidence-based foundation for the design of pre-service and in-service training within a coherent framework of career practice emphasises a developmental approach to capacity building. It takes into account that ICT is used both on a self-help basis and as part of face-to-face and distance service delivery (e.g. Sampson \& Makela, 2014). The results revealed five general approaches to social media and competency for social media (For details about the study's results, see Kettunen, 2017). These encompass a passive approach and informationcentred, communication-centred, collaborative career exploration and co-careering approaches (Kettunen, 2017). This gives a basis and establishes a continuum to work with, thus resulting in the provision of training with opportunities to experiment and practice with ICT and social media in a broader way. Specific practitioner competencies addressed during the course include proficiency in locating, evaluating, and using online content; being a versatile and thoughtful writer; being able to generate and sustain engaging and constructive online discussion; and creating a visible and trusted online presence (Kettunen, 2017). Emphasis was also placed on interventions that foster collaborative learning among peer group members (Kettunen et al., 2015). Throughout the course, the use of information and communication technology in guidance and counselling was linked to ethical issues. Peterson, Sampson, Reardon, and Lenz's (2008) cognitive information processing approach was used to illustrate how theory can be deployed to guide ICT-based career counselling and guidance practice.

\section{Information}

The most common use of ICT in career guidance is the dissemination of career information (Bimrose, Hughes, \& Barnes, 2011; Hooley, Hutchinson, \& Watts, 2010; Watts, 2002). The course seeks to enhance students' ability to identify and evaluate online career information and resources and the creative use of these tools to meet the client's needs.

In general terms, career information is that which is specific to occupations or to the career development process (Osborn, 2012). It includes information about education and training and employment and work opportunities (e.g. Sampson \& Osborn, 2014). The internet is the first contact point for many seeking to explore 
new learning and work opportunities for themselves. When using web search features to find specific information on industries and occupations, the identified resources are likely to contain social media-based information. Social mediabased career information is occupational, educational, training, and employment information developed and disseminated by users of the information (Sampson, Osborn, Kettunen, Hou, Miller, \& Makela, 2018).

The quality and validity of career information has been an issue for some time (e.g. Offer \& Sampson, 1999) and remains so today (e.g. Kettunen \& Makela, 2019; Sampson \& Makela, 2014). Appropriately selecting and using career information is dependent on individuals and clients having skills in information literacy and digital literacy. Guidance practitioners have an important role in helping individuals and clients to evaluate and use career information as well as supporting the development of the literacy of their clients (Hooley et al., 2010). Information literacy involves the ability to identify one's information needs and to locate, access, evaluate and use information efficiently. As defined by Martin (2008), digital literacy is the ability to use digital tools to find, sort, analyse and synthesise information and resources; to effectively communicate with others; and to construct new knowledge in the context of specific life situations involving reflection and social action. In the context of career guidance, Hooley (2012) characterised digital literacy as the capacity to critically (a) understand the nature of career information online, (b) analyse the origins of that information and (c) assess its utility.

During the course, students shared career information and online resources and described how these have been used or could best be used to meet the client's need. The aim of these exercises was to illustrate the multiple types and sources of information that can be used to enhance career services. Additionally, examples of software evaluation criteria (NCDA, 1991) were distributed and discussed in small groups. Students reviewed the assigned sections and shared their observations with the rest of the group. Finally, students worked with case examples to develop their awareness of potential sources of invalidity in social media-based career information. The aim of these activities was to enhance students' awareness of existing criteria and their ability to identify and evaluate online career information and resources.

\section{Communication}

Although ICT is increasingly used for communication, it remains relatively underutilised in career services (e.g. Bimrose, Kettunen, \& Goddard, 2015), and the course aimed to enhance students' ability to use ICT for one-to-one communication. This communication can be asynchronous (where receipt of a message involves a delay) or synchronous (where people communicate simultaneously in real time). Training was provided in text-based communication using email and chat, as these are currently most commonly used in guidance service provision. 
E-mail. Career practitioners increasingly use email when assisting clients. To enhance this capability, the course included guidance and counselling experiences from the Swedish eGuidance service (Vägledningsinfo.se). When eGuidance services first began in Sweden, social media was relatively new, and communication predominantly involved phone and e-mail. The course initiated discussion of the skills needed to use email to engage in a professional and ethical way with client concerns and explored guidance practitioners' experiences of using email (Möller, 2004) and how these were evaluated during the period 2005-2008 (Lindberg, 2008) and systematically applied in practice.

One key issue related to the exclusive use of text and writing is to develop a relationship that supports the client's career process. A basic introduction to writing skills drew on Marcus Offer's checklist entitled Using Information \& Communications Technology Effectively in Guidance Service and Giving Guidance by Email (2004a, 2004b). Course participants also reviewed Career Counselling by email - Guidelines for practitioners (Brown, 2006) in order to discuss and reflect on how this knowledge might inform structured methods.

The course also examined how email communication differs from more traditional face-to-face meetings, using practical examples of how email allows people to use their own words in their own time, place and context rather than in a physical location at a specified time, where the career guidance counsellor is in control. In email communication issues are initiated by the client in their own words, and are not first filtered through guidance professional's skilled use of active listening, empathy, and body language to prompt and probe (Egan, 2010). By working asynchronously, both client and counsellor can communicate at their own pace, giving them time to gather their thoughts without any pressure to share immediately. Course participants shared experiences and examples related to time management, email layout and different styles of response.

The course included e-mail activities. Examples of authentic and anonymized e-mail cases were distributed, and students analysed these in groups, discussing the emotions vocalised in writing and questions raised. They went on to discuss how to address the case and worked together to formulate an email response. The aim of the exercises was to point out the possibilities of using empathic responses and summarisation even in a written context. Furthermore, the cases and discussions provided opportunities for students to increase their understanding and enhance skills on how guidance and counselling by email can be practiced.

Chat. Chat is a relatively recent addition to guidance service, but has already shown great potential. To enhance students' use and to broaden and deepen their knowledge of chat in professional practice, the course included an introduction to Danish eGuidance and their communication model.

When Danish eGuidance was formed in the beginning of 2011, career guidance counsellors had very limited experience of chatting in a professional context, and the massive user demand on the medium quickly triggered the need for a common 
approach to this mode of guidance. For that reason, eGuidance developed a communications model (the 4C model) based on well-known theories such as Egan (1994, 2010), Rogers (1980) and Lindh (1997). The eGuidance 4C model involves four phases: contact-contract-communication-conclusion. The counsellor can jump between phases, each of which has different goals and content.

(a) The initial contact phase seeks to establish and maintain a good relationship with the client. The counsellor focuses on active listening to understand the client's situation and to provide personalised advice while encouraging them to reflect on their own needs and interests.

(b) The contract phase seeks to co-define the focal issue of the virtual guidance session in collaboration with the client by asking targeted questions such as 'What shall we talk about?' or 'What question would you like to address?' Counsellors often return to this phase as the session progresses, and new questions or issues emerge on the basis of their interaction with the client.

(c) In the communication phase, the counsellor processes the information received from their client and tries to put their issue in perspective. To this end, eGuidance counsellors interact with their clients with questions or remarks such as 'Is it okay if I offer you some links during the chat?'; 'One moment please. I am just trying to find an answer'; or 'Let me ask a colleague, and I will get back to you in a few minutes'.

(d) During the conclusion phase, the counsellor provides information and/or instructions regarding the focal issue defined during the contract phase and seeks to evaluate the client's readiness to act. Instructions typically involve exploring directly a suggested education or career path and reflecting on different options.

During the course, students undertook activities related to their own knowledge and use of chat. The aim was to encourage reflection on chat as a medium for guidance and counselling and to acknowledge possible differences in how chat is used across the Nordic countries. They also worked with the $4 \mathrm{C}$ model; examples of authentic and anonymised chats were distributed, and students analysed the chats in small groups. They identified the different phases of the $4 \mathrm{C}$ model in the chat, noting parts that were functioning well or less well as a means of exploring the application of the $4 \mathrm{C}$ model and how chat functions in a guidance and guidance context. Secondly, students gained direct experience of chatting by working in pairs; one student played the client who contacted the other student (the counsellor) with a personal dilemma. The $4 \mathrm{C}$ model was used as a toolbox, providing the eGuidance counsellor with concrete proposals for questions and phrases in each phase. By switching roles, both gained experience as counsellor and client. The aim was to illustrate variations and to provide the students with opportunities to experiment and practice using chat in a professional context.

\section{Collaborative Career Exploration}

In collaborative career exploration, knowledge is shared in purposefully designed online space among individuals and practitioner as they work towards common 
learning goals - for example, understanding the question at hand or solving a problem. Practitioners' ability to design a space that integrates self-directed materials with interactive communication and knowledge of methods, techniques and activities that enhance participation and interaction in online discourse and foster collaborative processes in career learning among peer group members are highlighted (e.g. Kettunen, 2017). Learners are not passive recipients but active in their pursuit of knowledge as they participate in discussion, search for information and exchange opinions with their peers. The course aimed to enhance students' skills and knowledge in devising interventions that foster collaborative career learning among peers.

During the course, the five-stage model of structured learning activities (Salmon, 2005) was introduced and discussed as a means of creating interaction and participation. The first two stages of Salmon's model seek to acclimatise the learner to the online environment and develop a supportive social context. The third stage is information exchange, in which learners interact with course materials and online activities, providing each other with further resources. In the fourth, stage, knowledge construction, learners work collaboratively, sharing ideas, posing problems and challenging each other in the spirit of inquiry. The final stage invites participants to take responsibility for their own learning and to reflect on it. Additionally, examples and experiences of online communities using synchronous communication in richer mediums like web-based video conferencing systems were shared. Throughout the course, students use an online learning platform that models the presented model to gain experience of collaborative career exploration.

Collaborative career exploration activities during the course included a task to be completed in a virtual meeting. Students were presented with a case scenario involving an ethical dilemma and were asked to work through it by defining ethical issues, identifying ideal resolutions and brainstorming strategies for practice in small groups in a virtual meeting room. Discussion and group reflection processes were recorded using audio and video. As well as its collaborative aspect, the aim of this exercise was to allow students to experience use of a virtual meeting room.

\section{Co-Careering}

In recent years, social media has gradually become part of daily practice for many career practitioners (e.g. Dyson, 2012; NACE, 2013; Osborn \& LoFrisco, 2012), enabling co-careering in which shared expertise and meaningful co-construction on career issues take place with and among community members (Kettunen, 2017, p. 41). To enhance students' co-careering skills and understanding, the training focuses on how to create and express a visible and trusted online presence, as well as questions pertaining to ethical practice in social media.

Social media enables individuals and groups to build common understandings and shared meanings based on content, community and Web 2.0 technology (Ahlqvist, 
Bäck, Heinonen, \& Halonen, 2010; Kolbitsch \& Maurer, 2006). Thus, it primarily does not refer to a particular set of technologies but to types of practices (Bonderup Dohn, 2009). Each user has the opportunity to play an active, content-producing and interactive role, or serve as a bystander. The integration of social media into career services has prompted the redesign of service delivery, especially regarding the role of the practitioner. In guidance processes, one can discern an evolution in the locus and nature of control as the practitioner moves from controlling the process to being a participant. Today the client has the possibility to choose and decide how, when and where they would like to communicate. The client can even control the process; if one no longer wishes to participate, it is easy to exit online, making the client more independent. Barnes, La Gro, and Watts (2010, p. 30) described this paradigm shift as an evolution from 'provider-led' to 'user-led' career services. Successful integration of social media in career services depends not only on available skills or technical facilities but on practitioners' willingness to accept the changes that new technology brings to service delivery (Kettunen, Vuorinen, \& Sampson, 2013, 2015).

The key to success on social media is to establish clear goals and ensure that your actions work to achieve these goals (Rutledge, 2010). During the course examples and experiences of using social media (such as Facebook, LinkedIn, Youtube) in career services were shared. Activities during the course included group discussions about social media's pros and cons. Furthermore, social media engagement tactics were explored and students practiced creating social media posts that encouraged people to interact. During the course, emphasis was also placed on more conscious involvement in online communities in which meanings and understandings are coconstructed. To utilise social media for co-careering, the practitioner must become an active participant by acquiring the requisite skills and establishing a visible, approachable and trusted presence (Kettunen et al., 2015; Sampson et al., 2018). Building a reliable and authentic image of oneself within the relevant communities requires mindful online presence, monitoring and actively updating one's online profiles; it also requires a practical understanding of the means by which this presence is conveyed to others online (Kettunen, 2017).

The course instructors referred to empirical examples of strategies for operationalising a visible and trusted online presence in professional practice. To begin, they distributed examples of how different clients might use social media for occupational, educational, and employment exploration. Students worked through the examples, identifying the phases in which co-careering occurred. The aim of this exercise was to give students examples of co-careering and offering a possibility to reflect on one's own future practice.

\section{DISCUSSION}

Career practitioners' capacity building is crucial for the successful integration of ICT in careers practice. This Nordic jointly developed international course provides 
a concrete model for bridging the skills gap in career practitioners' initial and continuing training, using a research-based framework (Kettunen, 2017) for ICT competency development. Members of the development team have gone to lengths to ensure that the course curriculum and material being developed are pedagogically and technically strong by incorporating relevant current research and methods into the overall course design. The team has challenged themselves and sought, and continue to seek, ways to develop the course and the activities that engage the students both in content and skill development by obtaining ideas for course improvements from course participants. Furthermore, the development of the course aligns with Åkerlind et al.'s (2014) view that phenomenographic studies can be used to improve the design and evaluation of services and the associated curriculum, and more studies of this kind can be expected to contribute to further advances in the field of guidance and counselling.

\section{REFERENCES}

Ahlqvist, T., Bäck, A., Heinonen, S., \& Halonen, M. (2010). Road-mapping the societal transformation potential of social media. Foresight, 12(5), 3-26. doi:10.1108/14636681011075687

Åkerlind, G. S. (2008). A phenomenographic approach to developing academics $>$ understanding of the nature of teaching and learning. Teaching in Higher Education, 13(6), 633-644. doi:10.1080/ 13562510802452350

Åkerlind, G. S., McKenzie, J., \& Lupton, M. (2014). The potential of combining phenomenography, variation theory and threshold concepts to inform curriculum design in higher education. In J. Huisman \& M. Tight (Eds.), Theory and method in higher education research II (International Perspectives on Higher Education Research, 10, pp. 227-247). Bingley: Emerald Group.

Andreassen, I., \& Einarsdottir, S. (2012). Diverse history, common ground and joint future. The education of career guidance and counselling professionals in the Nordic and Baltic countries. Report of a VALA development project 1 on Curricular development.

Barnes, A., La Gro, N., \& Watts, A. G. (2010). Developing e-guidance competencies: The outcomes of a two-year European project to transform the professional development of career guidance practitioners. Career Research and Development: The NICEC Journal, 25, 26-32.

Bimrose, J., Barnes, S.-A., \& Atwell, G. (2010). An investigation into the skills needed by connexions personal advisers to develop internet-based guidance. Reading: CfBT Education Trust.

Bimrose, J., Hughes, D., \& Barnes, S.-A. (2011). Integrating new technologies into careers practice: Extending the knowledge base. London: UK Commission for Employment and Skills.

Bimrose, J., Kettunen, J., \& Goddard, T. (2015). ICT - The new frontier? Pushing the boundaries of careers practice. British Journal of Guidance \& Counselling, 43(1), 8-23. doi:10.1080/03069885.2 014.975677

Bonderup Dohn, N. (2009). Web 2.0: Inherent tensions and evident challenges for education. International Journal of Computer Supported Collaborative Learning, 4(3), 343-363. doi:10.1007/s11412-0099066-8

Bowden, J., \& Marton, F. (1998). The university of learning: Beyond quality and competence. London: Kogan Page.

Brown, C. (2006). Career Counselling by email - Guidelines for practitioners.

Brown, J. S., Collins, A., \& Duguid, P. (1989). Situated cognition and the culture of learning. Educational Research, 18(1), 32-42. doi:10.3102/0013189X018001032

Cedefop. (2009). Professionalising career guidance: Practitioner competences and qualification routes in Europe (Cedefop panorama series 164). Luxembourg: Office of the European Union. 
Cedefop. (2011). Lifelong guidance across Europe: Reviewing policy progress and future prospects. Luxembourg: Publications Office of the European Union.

Dyson, E. (2012). Face-to-Facebook: A blended approach to careers work. Journal of the National Institute for Career Education and Counselling, 29(1), 27-32.

Egan, G. (1994). The skilled helper: A problem-management approach to helping (5th ed.). Belmont, CA: Thomson Brooks/Cole Publishing Co.

Egan, G. (2010) The skilled helper - A problem-management and opportunity-development approach to helping (9th ed.). Belmont, CA: Brooks/Cole Cengage Learning.

Eurobarometer. (2014). Special Eurobarometer 417. European area of skills and qualifications. Brussels: European Commission.

European Commission. (2014). European reference competence profile for PES and EURES counsellors. Brussels.

European Council. (2004, May 18). Draft resolution of the council and of the representatives of the member states meeting within the council on strengthening policies, systems and practices in the field of guidance throughout life in Europe. Council of the European Union, Brussels, EU.

European Council. (2008). Draft resolution of the council and of the representatives of the government of the member states, meeting within the council, on better integrating lifelong guidance into lifelong learning strategies. Brussels, EU.

European Lifelong Guidance Policy Network (ELGPN). (2010). Lifelong Guidance Policies: Work in progress. A report on the work of the European Lifelong Guidance Policy Network 2008-2010. Jyväskylä: University of Jyväskylä.

Hooley, T., Hutchinson, J., \& Watts, A. G. (2010). Careering through the web. The potential of Web 2.0 and 3.0 technologies for career development and career support services. London: UK Commission for Employment and Skills.

Hoonakker, P. (2014). Information and communication technology and quality of working life: Backgrounds, facts, and figures. In C. Korunka \& P. Hoonakker (Eds.), The impact of ICT on quality of working life (pp. 9-23). Dordrecht: Springer.

Högskoleverket. (2006). Utvärdering av studie- och yrkesvägledarutbildningen i Sverige [Evaluation of study and career guidance training in Sweden] (Högskoleverkets rapportserie 2006:42 R). Stockholm: Högskoleverket.

International Telecommunication Union (ITU). (2017). Measuring the Information Society Report 2017. Geneva: ITU.

Kettunen, J. (2017). Career practitioners' conceptions of social media and competency for social media in career services (Studies, 32. Dissertation, Studies, 32). University of Jyväskylä, Finnish Institute for Educationa Research, Jyväskylä, Finland.

Kettunen, J., \& Makela, J. (2019). Career practitioners' conceptions of ethical practice in social networking. International Journal for Educational and Vocational Guidance, 19(3), 345-362. doi:10.1007/s10775-018-9383-4

Kettunen, J., \& Sampson Jr., J. P. (2019). Challenges in implementing ICT in career services: Perspectives from career development experts. International Journal for Educational and Vocational Guidance, 19(1), 1-8. doi:10.1007/s10775-018-9365-6

Kettunen, J., Sampson Jr., J. P., \& Vuorinen, R. (2015). Career practitioners' conceptions of competency for social media in career services. British Journal of Guidance and Counselling, 43(1), 43-56. doi:1 $0.1080 / 03069885.2014 .939945$

Kettunen, J., \& Tynjälä, P. (2018). Applying phenomenography in guidance and counselling research. British Journal of Guidance \& Counselling, 46(1), 1-11. doi:10.1080/03069885.2017.1285006

Kettunen, J., Vuorinen, R., \& Sampson Jr., J. P. (2013). Career practitioners' conceptions of social media in career services. British Journal of Guidance \& Counselling, 41(3), 302-317. doi:10.1080/030698 85.2013 .781572

Kettunen, J., Vuorinen, R., \& Sampson Jr., J. P. (2015). Practitioners' experiences of social media in career services. The Career Development Quarterly, 63(3), 268-282. doi:10.1002/cdq.12018

Kolbitsch, J., \& Maurer, H. (2006). The transformation of the web: How emerging communities shape the information we consume. Journal of Universal Computer Science, 12(2), 187-213. 


\section{J. KETTUNEN ET AL.}

Lindberg, M. (2008). Vägar till vägledning - En historia om en oberoende, nationell och flexibel vägledningstjänst. NSHU 2008:08.

Lindh, G. (1997). Samtalet $i$ studie- och yrkesvägledningsprocessen [The interview in the career counselling process]. Stockholm: HLS Förlag.

Martin, A. (2008). Digital literacy and the "digital society." In C. Lankshear \& M. Knobel (Eds.), Digital literacies: Concepts, policies and practices (pp. 151-176). New York, NY: Peter Lang Publishing.

Marton, F. (1986). Phenomenography - A research approach investigating different understandings of reality. Journal of Thought, 21(3), 28-49.

Marton, F. (1994). Phenomenography. In T. Husén \& T. N. Postlethwaite (Eds.), The international encyclopedia of education (2nd ed., pp. 4424-4429). Oxford: Pergamon Press.

Marton, F., \& Booth, S. (1997). Learning and awareness. Mahwah, NJ: Lawrence Erlbaum Associates.

Marton, F., \& Tsui, A. B. M. (2004). Classroom discourse and the space of learning. Mahwah, NJ: Lawrence Erlbaum Associates.

Mason, J. (2002). Researching your practice: The discipline of noticing. London: Falmer Press.

Mezirow, J. (1990). Fostering critical reflection in adulthood: A guide to transformative and emancipatory learning. San Francisco, CA: Jossey-Bass Publishers.

Möller, J. (2005). Kartläggning av e-post till studievägledningen vid myndigheten för Sveriges nätuniversitet [A qualitative survey of incoming e-mail to the career guidance service at the Swedish Netuniversity]. Retrieved from https://core.ac.uk/download/pdf/16322914.pdf

National Association of Colleges and Employers (NACE). (2013). Career services use of social media technologies. Retrieved from http://www.careeradvisoryboard.org/research/career-services-use-ofsocial-media-technologies--may-2013.html

Norges offentlige utredninger (NOU). (2016). Norge i omstilling. Karriereveiledning for individ og samfunn [Career guidance for the individual and the society] (Vol. 7). Oslo: Kunnskapsdepartementet.

Offer, M. (2004a). Giving guidance by email. An advicers' checklist. Manchester: Graduate Prospects and HECSU.

Offer, M. (2004b). What is e-guidance? Using information and communications technology effectively in guidance services. Manchester: Graduate Prospects and HECSU.

Offer, M., \& Sampson, J. P. (1999). Quality in the content and use of information and communications technology in guidance. British Journal of Guidance \& Counselling, 27(4), 501-516. doi:10.1080/ 03069889908256286

Organisation for Economic Co-operation and Development (OECD). (2004a). Career guidance and public policy: Bridging the gap. Paris: OECD.

Organisation for Economic Co-operation and Development (OECD). (2004b). Career guidance: A handbook for policy makers. Paris: OECD.

Osborn, D. S. (2012). The role of career information and technological resources in career planning. In B. H. Suddarth \& D. M. Reile (Eds.), Facilitating career development, student manual (3rd ed., pp. 7-3 to 7-24). National Career Development Association.

Osborn, D. S., Dikel, M. R., \& Sampson, J. P. (2011). The internet: A tool for career planning (3rd ed.). Broken Arrow, OK: National Career Development Association.

Osborn, D. S., \& LoFrisco, B. M. (2012). How do career centers use social networking sites? The Career Development Quarterly, 60(3), 263-272. doi:10.1002/j.2161-0045.2012.00022.x

Peterson, G. W., Sampson Jr., J. P., Reardon, R. C., \& Lenz, J. G. (2008). Cognitive information processing model. In F. Leong (Ed.), Encyclopedia of counseling (Vol. 4, pp. 1504-1509). Thousand Oaks, CA: Sage Publications.

Rogers, C. R. (1980). A way of being. Boston, MA: Houghton Mifflin.

Runesson, U. (2006). What is it possible learn? On variation as a necessary condition for learning. Scandinavian Journal of Educational Research, 50(4), 397-410.

Rutledge, P. A. (2010). Using LinkedIn. Indianapolis, IN: Que Publishing.

Salmon, G. (2004). E-moderating: The key to teaching and learning online (2nd ed.). London: Routledge.

Sampson Jr., J. P., Kettunen, J., \& Vuorinen, R. (2019). The role of practitioners in helping persons make effective use of ICT in career interventions. International Journal for Educational and Vocational Guidance. doi:10.1007/s10775-019-09399-y 
Sampson Jr., J. P., \& Osborn, D. S. (2014). Using information and communication technology in delivering career interventions. In P. J. Hartung, M. L. Savickas, \& W. B. Walsh (Eds.), APA handbook of career intervention: Applications (Vol. 2, pp. 57-70). Washington, DC: American Psychological Association.

Sampson, J. P., Osborn, D., Kettunen, J., Hou, P.-C., Miller, A. K., \& Makela, J. P. (2018). The validity of social media-based career information. The Career Development Quarterly, 66(2), 121-134. doi:10.1002/cdq.12127

Sampson, J. P., \& Makela, J. P. (2014). Ethical issues associated with information and communication technology in counseling and guidance. International Association for Educational and Vocational Guidance Journal, 14, 135-148. doi:10.1007/s10775-013-9258-7

Sultana, R. G. (2004). Guidance policies in the knowledge society: Trends, challenges and responses across Europe: A Cedefop synthesis report (Cedefop Panorama Series 85). Luxembourg: Office for Official Publications of the European Communities.

Sultana, R. G., \& Watts, A. G. (2006). Career guidance in public employment services across Europe. International Journal for Educational and Vocational Guidance, 6, 29-46. doi:10.1007/s10775-0060001-5

Säljö, R. (2001). Laring i praksis- et sosiokulturelt perspektiv [Learning in practice, a socio-cultural perspective]. Oslo: Cappelen akademiske forlag.

Zelloth, H. (2009). In demand: Career guidance in EU neighbouring countries. Luxembourg: Office for Official Publications of the European Communities.

Valtiontalouden tarkastusvirasto. (2015). Tuloksellisuustarkastuskertomus. Yhteistyö opintojen ohjauksessa ja uraohjauksessa [Cooperation for study and career guidance]. Helsinki: Valtiontalouden tarkastusviraston tarkastuskertomus [The National Audit Offices audit report 5/2015].

Vuorinen, R. (2006). Internet ohjauksessa vai ohjaus internetissä? Ohjaajien käsityksiä internetin merkityksestä työvälineenä [The Internet in guidance or guidance in the Internet? Perceptions of guidance practitioners on the use of the Internet as a tool in guidance] (Research Reports 19). Jyväskylä: University of Jyväskylä, Finnish Institute for Educational Research.

Watts, A. G. (2002). The role of information and communication technologies in integrated career information and guidance systems: A policy perspective. International Journal for Educational and Vocational Guidance, 2(3), 139-155. doi:10.1023/A:1020669832743

Watts, A. G., \& Sultana, R. G. (2004). Career guidance policies in 37 countries: Contrast and common themes. International Journal for Educational and Vocational Guidance, 4(2-3), 105-122. doi:10.1007/ s10775-005-1025-y 